\title{
PI3K|AKT/mTOR Pathway in Ovarian Cancer Treatment: Are We on the Right Track?
}

\section{Bedeutung des PI3K|AKT/mTOR-Signalwegs für die Behandlung des Ovarialkarzinoms: Sind wir auf dem richtigen Weg?}

Authors

Maria Luisa Gasparri ${ }^{1,2}$, Erlisa Bardhi ${ }^{1}$, Ilary Ruscito ${ }^{1}$, Andrea Papadia ${ }^{2}$, Ammad Ahmad Farooqi ${ }^{3}$, Claudia Marchetti ${ }^{1}$, Giorgio Bogani ${ }^{4}$, Irene Ceccacci ${ }^{1}$, Michael D. Mueller ${ }^{2}$, Pierluigi Benedetti Panici ${ }^{1}$

Affiliations

1 Department of Gynecology, Obstetrics and Urology, "Sapienza" University of Rome, Rome, Italy

2 Department of Obstetrics and Gynecology, University of Berne, Berne, Switzerland

3 Laboratory for Translational Oncology and Personalized Medicine, Rashid Latif Medical College, Lahore, Pakistan

4 Department of Gynecologic Oncology, IRCCS National Cancer Institute, Milan, Italy

\section{Key words}

everolimus, mTOR inhibitors, ovarian cancer, target therapy, temsirolimus, PI3K/AKT/mTOR

Schlüsselwörter

Everolimus, mTOR-Inhibitoren, Ovarialkarzinom, gezielte Therapie, Temsirolimus, PI3K/AKT/mTOR

received 31.5.2017

revised 2.8 .2017

accepted 25.8.2017

\section{Bibliography}

DOI https://doi.org/10.1055/s-0043-118907

Geburtsh Frauenheilk 2017; 77: 1095-1103 @ Georg Thieme

Verlag KG Stuttgart · New York | ISSN 0016-5751

\section{Correspondence}

Ilary Ruscito, MD

Department of Gynecology, Obstetrics and Urology,

Sapienza University of Rome

Viale del Policlinico, 155, 00161, Rome, Italy

ilary.ruscito@uniroma1.it

\section{ABSTRACT}

The high recurrence rate and the low overall survival in ovarian cancer suggest that a more specific therapeutic approach in addition to conventional treatment is required. Translational and clinical research is investigating new molecular targets in order to find an alternative way to affect tumor growth and to minimize the overlap of toxicity of antiblastic agents. Given its implication in many cellular activities including regulation of cell growth, motility, survival, proliferation, protein synthesis, autophagy, transcription, as well as angiogenesis, PI3K/AKT/ mTOR is one of the most investigated intracellular signaling pathways. A dis-regulation of this pathway has been shown in several tumors, including ovarian cancer. In this setting, mTor proteins represent a potential target for inhibitors, which could ultimately play a pivotal role in counteracting cellular proliferation. Recently, mTor inhibitors have been approved in the treatment of pancreatic neuroendocrine tumors, mantle cell lymphoma and renal cancer. Clinical trials have assessed the safety of these drugs in ovarian cancer patients. Ongoing phase I and II studies are evaluating the oncologic outcome of mTor inhibitor treatment and its effect in combination with conventional chemotherapy and target agents.

\section{ZUSAMMENFASSUNG}

Die hohe Rückfallquote und die allgemeine niedrige Gesamtüberlebensrate beim Ovarialkrebs weisen darauf hin, dass neben der herkömmlichen Behandlung zusätzlich eine spezifischere Therapie benötigt wird. In der translationalen und klinischen Forschung wird derzeit nach alternativen molekularen Zielstrukturen gesucht, die einerseits das Tumorwachstum aufhalten und andererseits die überlappende Toxizität von wachstumshemmenden Wirkstoffe minimieren könnten. Da PI3K/AKT/mTOR viele Zellfunktionen steuern, u. a. die Regulierung des Zellwachstums, Motilität, Überleben, Proliferation, Proteinsynthese, Autophagozytose, Transkription und Angiogenese, gehören sie zu den meist untersuchten intrazellulären Signalwegen. Eine Deregulierung dieses Signalweges wurde bei einigen Tumoren festgestellt, darunter auch für das Ovarialkarzinom. Vor diesem Hintergrund könnten mTorProteine potenzielle Ziele für Inhibitoren sein, die dann eine Schlüsselrolle bei der Hemmung der Zellproliferation spielen könnten. Vor Kurzem wurden mTor-Inhibitoren zur Behandlung von neuroendokrinen Tumoren der Bauchspeicheldrüse, Mantelzell-Lymphomen und Nierenkrebs zugelassen. Klinische Studien haben die Sicherheit dieser Medikamente in Patientinnen mit Eierstockkrebs untersucht. Aktuell werden Phase-I und -II-Studien durchgeführt, um die onkologischen 
Ergebnisse nach einer Behandlung mit mTOR-Inhibitoren und die Auswirkungen dieser Therapie in Kombination mit kon- ventioneller Chemotherapie und Target-Wirkstoffen zu bewerten.

\section{Introduction}

In the past decades a significant amount of research has focused on ovarian cancer. The better understanding of the molecular processes that occur in the cancerous cells, the receptors expressed on the cancerous cells and molecular mechanisms involved in carcinogenesis and tumor progression has led to the development and use of new targeted therapies [1-15]. Concomitantly, through the improvement of surgical techniques and medical support of the patients the optimal cytoreduction rates have progressively increased [16-22]. Unfortunately, despite these efforts and improvements ovarian cancer still remains the deadliest gynecological cancer and it is estimated that, in the USA, approximately 14180 women died of ovarian cancer in 2015 [23]. Its aggressiveness is mostly related to the late presentation of the symptoms. As a result, more than half of the diagnoses are made at an advanced stage. The current standard treatment of advanced disease ovarian cancer consists in a radical surgery and by systemic chemotherapy with carboplatin and paclitaxel, delivered either adjuvantly or neoadjuvantly [24]. Thanks to the continuous research and the development of new treatments, the prognosis of women affected by ovarian cancer is better than it used to be. However, with an overall survival of roughly $40 \%$ at five years, it is far from satisfactory [25]. Furthermore, approximately $25 \%$ of the patients will suffer a relapse within 6 months after completion of their treatment [26]. Platinum-resistant recurrences are extremely difficult to treat and often lead to death in a short interval of time. Hence, there is urgent need to find new therapeutic strategies to improve the current clinical results.

Recently, particular attention has been paid to the molecular aspects of ovarian cancer, in an attempt to better understand and consequently treat the disease. Extensive genomic analysis using molecular profiling performed by the Cancer Genome Atlas helped in identifying some of the most common alterations involving metabolic and signaling pathways in ovarian cancer [27].

Among them, the PI3K/Akt/mTor pathway is one of the most investigated intracellular signaling pathways, given its implication in many cellular activities including regulation of cell growth, motility, survival, proliferation, protein synthesis, autophagy, transcription as well as angiogenesis [28]. Studies adopting comparative genomic hybridization arrays have found PI3K/AKT/mTOR to be the most frequently altered intracellular pathway in ovarian cancer $[29,30]$. This is a complex pathway that integrates a number of upstream inputs ranging from growth factors (epidermal growth factor, tumor growth factor etc.), tyrosine-kinase receptors (insuline growth factor 1 receptor, epidermal growth factor receptor, HER2) and other membrane receptors such as Met, or RAS-mediated cross talk with the Ras-Raf-Mek-Erk pathway [31]. The interaction of the above mentioned compounds with PI3K activates downstream effectors such as AKT and the mTORC1 complex.

\section{Overview of the PI3K/Akt/mTor Pathway}

PI3Ks are part of the lipid-kinases family, originally discovered in the 1980s [32]. Based on their structure and substrate specificity, PI3Ks have been categorized into 3 distinct classes: I-II and III. Class I PI3Ks is divided into class IA and class IB based on the differences in their activating receptors. In class IA PI3K are grouped heterodimers consisting of a p85 regulatory subunit and a p110 catalytic subunit, which has 3 isomers ( $\alpha, \beta$ and $\gamma$ ) respectively encoded by three distinct genes, PIK3CA, PIK3CB, and PIK3CD. Of these, the most frequently mutated in human cancer appears to be PIK3CA [33].

When bound to its ligands, PI3K results in the allosteric activation of the $\mathrm{p} 110$ catalytic subunit that finally leads to phosphorylation of phosphatidylinositol 4,5-bisphosphate (PIP2) into the active second messenger PIP3, thus triggering the PDK1 proteins and recruiting AKT to the plasma membrane. Phosphatase and tensin homolog (PTEN) can specifically catalyze the dephosphorylation of the $\mathrm{PI}(3,4,5) \mathrm{P3}$, converting $\mathrm{PI}(3,4,5) \mathrm{P} 3$ back to $\mathrm{PI}(4$, 5)P2, thereby negatively regulating PI3K pathway [34]. A similar negative regulation action is carried out by Inositol polyphosphate 4-phosphatase type 2 (INPP4B) that hydrolyzes PI(3, 4)P2. Consequently, mutation or blockade of the above pathway can ultimately lead to an independent cell growth and enhanced overall motility, due to the lack of negative regulators of the PI3K/AKT/ mTOR cascade [35].

Activated AKT (also known as protein kinase B) regulates a large number of downstream mediators, ultimately controlling critical cell survival and metabolic processes [31]. It can activate mTORC1 directly, by phosphorylating the Ser2448 or indirectly by phosphorylating tuberous sclerosis complex 2 (TSC2). TSC1/ TSC2 (tuberous sclerosis complex proteins) work as an activating protein for the Ras homolog enriched in brain (Rheb)-GTPase, thus promoting the conversion of Rheb-GTP into its inactive GDP form, which silences mTORC1 when accumulated [36]. By phosphorylating TSC2, AKT makes the complex TSC1/TSC2 inactive, thus indirectly stimulating mTor kinase activity.

Mammalian target of rapamycin (mTor) is a serine/threonine protein kinase, firstly identified in the budding yeast Saccharomyces cerevisiae during a test for resistance to the immunosuppressant drug rapamycin [37]. It performs its activities through 2 distinct complexes: mTORC1-Raptor and mTORC2-Rictor, which have recently emerged as key regulators of the differentiation of helper T cells [38].

When activated, mTORC1 phosphorylates ribosomal S6 kinase-1 (S6K-1) and eukaryote translation initiation factor 4E binding protein-1 (4EBP-1), both pivotal translation-regulating factors. The first one is implicated in translation of mRNA encoding for ribosomal proteins and elongation factors crucial for passage from G1 to S phase of the cell cycle. The second helps cell cycle pro- 
gression or angiogenesis through translation of mRNA encoding for cyclin D1, c-Myc, and hypoxia inducible factor-1 $\alpha$ [36].

mTORC2 consists of 7 proteins and different studies have found that, when activated, it phosphorylates kinases. In particular, it is worth mentioning the direct activation of AKT through phosphorylation at its hydrophobic motif (Ser473), thus promoting all AKT-mediated downstream implications that ultimately lead to cell growth [36].

Importantly, mTORC1, but not mTORC2, is inhibited by rapamycin. In addition, mTORC2 exerts a positive feedback activation on AKT.

\section{Alterations of the PI3K/AKT/mTOR Pathway in Ovarian Cancer}

The PI3K/AKT/mTOR pathway is activated in approximately $70 \%$ of ovarian cancer cases, thus promoting cellular growth, proliferation and cell survival through intricate series of hyperactive signaling cascades [39]. Its activation is associated with higher invasive and migratory capacities even within heterogeneous cell subpopulations co-existing within human ovarian cancer, thus making the $\mathrm{PI} 3 \mathrm{~K} / \mathrm{AKT} / \mathrm{mTOR}$ pathway a potential predictor of invasiveness for ovarian tumor cells [40].

Different mechanisms can persistently activate the mTor pathway in cancer. Other than upstream input, somatic activating mutations in the PIK3CA gene (encoding for the p110 catalytic subunit) were found in $12 \%$ of ovarian cancer cases [41].

From an oncogenic point of view, it has been recently well established that ovarian cancer represents a heterogeneous group of different neoplasms, each characterized by distinct etiology and phenotype [42]. In particular, Kurman et al. with their recent dichotomic classification of ovarian cancer subtypes, highlighted that type I tumors (mainly low-grade serous, low-grade endometrioid, mucinous, clear cells and Brenner carcinomas) develop from benign extraovarian lesions implanting on the ovary, which can successively transform into malignant lesions, whereas many type II carcinomas (including high-grade serous ovarian cancers) develop from intraepithelial carcinomas in the fallopian tube (STIC, serous tubal intraepithelial carcinomas) and rapidly disseminate to the ovary and extraovarian sites [43]. The different subtypes of ovarian cancers present since their origin with distinct genetic mutational panels $[42,43]$.

High-grade serous ovarian cancer reports rare mutations of the PI3K/Akt, in contrast to clear cell ovarian cancer (OCCC) and endometrioid adenocarcinoma. Gain of function PIK3CA-mutation has been suggested to occur in $30-40 \%$ of ovarian clear cell carcinomas and in $12-20 \%$ of endometroid ovarian carcinomas [44]. Mutations of the PIK3R1 gene encoding for the p85 regulatory subunit were found in $3.8 \%$ of ovarian cancer [45]. Other intrinsic mechanisms involved in $\mathrm{PI} 3 \mathrm{~K} / \mathrm{Akt} / \mathrm{mTor}$ hyperactivation in cancer include: mutations or amplifications in one of the AKT isoforms, loss of the negative regulator PTEN, loss or inactivating mutations in the tumor suppressors like TSC or LKB1 [30], or even loss of the INPP4B, which was found in up to $39 \%$ of ovarian cancer [34]. As a consequence, there is a gain in cell growth and prolifer- ation, angiogenesis and therefore a promotion of cell transformation and/or progression.

Inhibition of PI3K/Akt/mTor in mice models was found to delay tumor growth and prolong survival [46], providing practical proof of the importance of this pathway in oncogenesis and/or oncoprogression of ovarian cancer and of its possible targeting as new therapeutic strategy. Inhibitors of the PI3K/AKT/mTOR pathway can be classified into 4 main categories: mTor inhibitors, PI3K inhibitors, dual mTor/PI3K inhibitors and AKT inhibitors.

\section{mTor Inhibitors}

Rapamycin (sirolimus) is a chemical compound initially discovered in the 1970s as a product of Streptomyces Hygroscopicus bacteria growing in a soil sample originating from Easter Island [47]. It was initially developed as an antifungal and immunosuppressive drug but its anticancer potential was observed during the last decade [48]. Rapamycin and its analogues perform their inhibitory activity towards mTor, by initially binding the intracellular protein FK506-binding protein 12 (FKBP12). The rapamycin-FKBP12 complex interacts with the FKBP12-rapamycin-binding domain (FRB) of mTor, causing an allosteric transformation that ultimately leads to the mTor kinase activity inhibition $[32,35,49]$.

The lack of subsequent phosphorylation of S6K1 e 4EBP1 prevents CDK activation, resulting in cell cycle arrest in $\mathrm{G} 1 / \mathrm{S}$ [50].

Early clinical studies of mTOR inhibitors in cancer have shown promising results [37]. The most studied mTor inhibitors in ovarian cancer are: temsirolimus, everolimus, and ridaforolimus.

- Fig. 1 shows the PI3K/Akt/mTor pathway and the effects of mTOR-inhibitors.

\section{Temsirolimus}

The Gynecologic Oncology Group (GOG) conducted a phase II clinical trial investigating temsirolimus as single agent in 60 patients affected by recurrent epithelial ovarian and primary peritoneal cancers. Out of 54 eligible patients, $24.1 \%$ progressed after at least 6 months and $9.3 \%$ achieved a partial response. Adverse events reported were fatigue, gastrointestinal and metabolic alterations including 1 case of grade 3 renal failure and grade 4 pulmonary embolism [51]. Notably, tumor expression of cyclin D1 appeared to be associated with higher p4EBP1 and a greater likelihood of prolonged PFS and overall survival [51].

Fifteen gynecological cancer patients were enrolled by Temkin et al. in a trial investigating the effect of combined intravenous infusions of topotecan and temsirolimus $\left(1 \mathrm{mg} / \mathrm{m}^{2}\right.$ and $25 \mathrm{mg}$, respectively) once daily on days 1, 8 and 15 of a 28 day cycle. Temsirolimus alone was infused on day 22 of each cycle [52]. Temsirolimus was dose reduced to $15 \mathrm{mg}$ in some cases due to grade 3 thrombocytopenia. Nine out of 11 patients $(81.8 \%)$ reported stable disease throughout the almost 2-year study period.

Another regimen of weekly Temsirolimus was tested in Saitama, Japan, in patients with recurrent ovarian clear cell carcinoma, previously treated with at least 4 different therapy regimens. Among five evaluable patients, partial response was observed in one case (20\%) and stabilized disease was seen in another case (20\%). There were no toxicities greater than grade 3 , and no case 


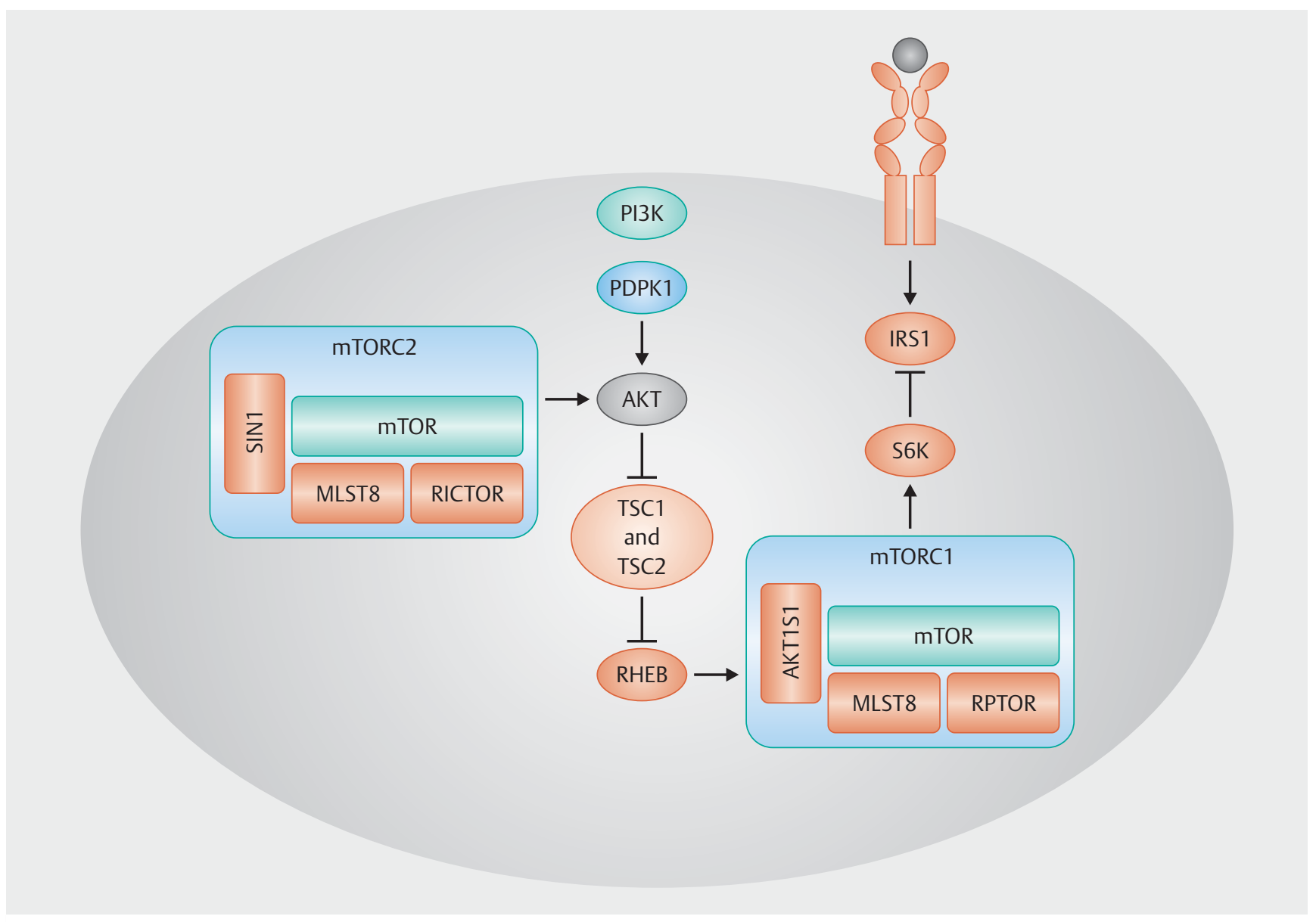

- Fig. 1 PI3K/Akt/mTor pathway and effects of mTOR-inhibitors. Different signaling cascades have been shown to modulate mammalian target of rapamycin (mTOR). Growth factor mediated intracellular signaling triggered PDPK1 to phosphorylate and activate PKB/AKT. AKT directly phosphoinhibited TSC2 which consequently resulted in activation of mTOR via RHEB resulting in phosphorylation of protein S6 kinase beta-1 (S6K1). Newer treatment strategies should focus on inhibition of mTORC1 and mTORC2 multi-proteins assemblies and on treatments that combine mTOR inhibitors with different interconnected pathway inhibitors.

of treatment discontinuation due to severe toxicity was reported [53].

The combination of carboplatin, paclitaxel and temsirolimus in patients with advanced solid tumors has been evaluated in the attempt to assess safety, tolerability and antitumor activity by Kollmannsberger et al. [54]. Among 38 enrolled patients, 6 (16\%) were affected by ovarian cancer. The phase I study concluded that the recommended dose of the regimen should be carboplatin AUC $5 \mathrm{mg} / \mathrm{ml} / \mathrm{min}$ and paclitaxel $175 \mathrm{mg} / \mathrm{m}^{2}$, both given on day 1 , plus temsirolimus $25 \mathrm{mg}$ on days 1 and 8 . This regimen was well tolerated. In 17/38 patients, partial response with a median PFS of 7.4 months was observed, while $49 \%$ of patients had stable disease. Among the 6 included ovarian cancer patients, 3 reported a partial response and 3 experienced disease stabilization. Grade 4 adverse effects consisted of myelotoxicity and fatigue.

More recently, tesmirolimus was tested in a Phase Ib study in combination with pegylated liposomal doxorubicin (PLD) on advanced breast, endometrial and ovarian cancer patients [55]. Twenty patients received weekly escalating dose of temsirolimus combined with PLD 30 or $40 \mathrm{mg} / \mathrm{m}^{2}$ once per month. Eleven pa- tients (55\%) were affected by OC. The recommended Phase II dose was found to be temsirolimus $15 \mathrm{mg}$ plus PLD $40 \mathrm{mg} / \mathrm{m}^{2}$. Three patients (two with ovarian cancer) reported durable partial response lasting 10.1, 12.7 and 13.7 months. Further 8 patients (two with ovarian cancer) had a long lasting stable disease (median 6.4 months). Most frequent adverse events were nausea, fatigue, mucositis, and skin toxicity.

Another recent combination of solely target therapies consisted of bevacizumab plus temsirolimus administered on advanced gynecologic tumors [56]. Bevacizumab $2.5-15 \mathrm{mg} / \mathrm{kg}$ was given on day 1 together with temsirolimus $5-25$ on day 1,8 , 15 in three-weekly treatment cycles. Twenty-two patients out of 41 (54\%) had ovarian cancer. Two out of 22 ovarian cancer patients reported a partial response whereas further 4 ovarian cancer patients experienced disease stabilization lasting over 6 months. Most common grade 3/4 treatment-related toxicities were thrombocytopenia (10\%) and fatigue (7\%).

In 2016, the AGO-study group published a Phase II study of weekly temsirolimus $25 \mathrm{mg}$ administered to refractory/resistant ovarian cancer and advanced/recurrent endometrial carcinoma 
patients [57]. Half of the patients enrolled (22/44) had ovarian cancer. After 8 weeks of treatment, partial response and stable disease were 1 (4.5\%) and 7 (31.8\%), respectively, among the ovarian cancer population. Most common severe toxicities were gastrointestinal disorders and one patient reported a grade 4 ileus.

\section{Everolimus}

A phase I study carried out on 32 patients affected by solid tumors treated with a combination regimen of five milligrams three times weekly of everolimus plus panitumumab at $4.8 \mathrm{mg} / \mathrm{kg}$ and bevacizumab at $10 \mathrm{mg} / \mathrm{kg}$ every 2 weeks resulted to be safe and tolerable and showed a moderate clinical activity [58]. Four out of 32 patients (12.5\%) had recurrent ovarian cancer. Three of them showed clinical response lasting at least 6 months after the treatment. The most common grade 3-4 toxicities were electrolytic disorders (35\%), blood hypertension (16\%), skin rush (16\%) and mucositis (13\%).

A very recent study about the everolimus effects was carried out on ovarian cancer mouse models with the aim of assessing the relationship between everolimus efficacy and obesity [59]. The study hypothesis was justified by the observation that obesity leads to hyperactivation of the mTOR pathway in epithelial tissues, thus suggesting that mTOR inhibitors may be particularly effective in obese cancer patients [60]. Everolimus treatment resulted in the inhibition of tumor growth in both obese and lean mouse models but the analysis of the metabolic profile revealed that everolimus was able to alter tumor metabolism through different metabolic pathways between the two groups, thus suggesting that everolimus may act as antitumor agent through different ways among obese and lean ovarian cancer individuals.

\section{Other mTor inhibitors}

Another aspect to consider, when referring to mTor inhibitors, is their capacity to significantly sensitize Taxol-induced anti-ovarian cancer cell activity in vitro and in vivo, without causing apparent toxicities, as recently described by Zhang et al. in their study involving WYE-132, a mTORC1/2 dual inhibitor [61]. Furthermore, it appears that mTor inhibitors would have synergistic effects while used in combination with other target therapies, in particular the Ras/Raf/MEK pathway in endometrial carcinoma [62], which might justify assessment of the combined target therapies treatment effectiveness in ovarian cancer as well. However, in endometrial cancer recurrence setting, the clinical application of these drugs is currently controversial [63]. Another study conducted by Hussein et al., where a second-generation mTor inhibitor, Torin2 was tested, resulted in the inhibition of tumor cell viability and induction of apoptosis in epithelial ovarian cancer. In addition, this study found that combination in vivo of Torin2 and cisplatin synergistically inhibited tumor growth in nude mice, confirming the hypothesis that mTor inhibitors might serve as single agent therapies as well as in combination with other treatment options, acting either as synergic agents or sensitizing ones [61, 64]. In this scenario, it was also recently shown that the combination of PIK3 inhibitor BKM120 with PARP inhibitor olaparib resulted in reduced proliferation, survival and invasion in different ovarian cancer cell lines harboring PIK3CA mutations and in a significantly decreased BRCA1 expression in SKOV3 ovarian cancer cells [65].

Despite promising results in several studies, larger scale investigations are needed for a better characterization of the mTor inhibitors properties as antitumor agents. Up to date, no phase III trials have been reported on these drugs. - Table 1 summarizes the ongoing clinical trials involving mTor inhibitors in ovarian cancer. Preliminary results presented at the ASCO Meeting 2016 of the ongoing Phase II clinical trial investigating the effects of the combination "bevacizumab plus everolimus" in recurrent ovarian cancer patients (NCT01031381) [66], revealed that 14/50 (28\%) patients were progression-free at 6 months $(95 \% \mathrm{Cl} 16.67-$ $42.71 \%)$, with with $5(0.65 \%)$ grade 4 and 66 (8.64\%) grade 3 toxicities, mostly consisting in oral mucositis, fatigue, abdominal

- Table 1 Ongoing trials on mTor inhibitors in ovarian cancer.

\begin{tabular}{|c|c|c|c|c|c|}
\hline $\begin{array}{l}\text { ClinicalTrials.Gov } \\
\text { Identification } \\
\text { number }\end{array}$ & $\begin{array}{l}\text { Phase } \\
\text { study }\end{array}$ & Population & Scheduled & Course & Primary outcome \\
\hline NCT01031381 & II & $\begin{array}{l}\text { Recurrent ovarian, } \\
\text { peritoneal and fallopian } \\
\text { tube cancer }\end{array}$ & $\begin{array}{l}\text { Everolimus }+ \\
\text { bevacizumab }\end{array}$ & $\begin{array}{l}\text { Everolimus } 10 \text { mg orally daily continuously } \\
\text { Bevacizumab IV once every } 14 \text { days }\end{array}$ & 6 months PFS \\
\hline NCT02188550 & II & $\begin{array}{l}\text { Recurring/platinum } \\
\text { resistant ovarian/endo- } \\
\text { metrial cancer }\end{array}$ & $\begin{array}{l}\text { Everolimus + } \\
\text { letrazole }\end{array}$ & $\begin{array}{l}\text { Everolimus: } 10 \mathrm{mg} \text { orally daily } \\
\text { Letrazole: } 2.5 \mathrm{mg} \text { orally daily, } 28 \text { days cycle } \\
\text { Evaluation every } 3 \text { cycles }\end{array}$ & $\begin{array}{l}\text { Tumor response } \\
\text { to treatment }\end{array}$ \\
\hline NCT02283658 & II & $\begin{array}{l}\text { Relapsed hormone re- } \\
\text { ceptor positive ovarian, } \\
\text { fallopian tube or primary } \\
\text { peritoneal carcinomas }\end{array}$ & $\begin{array}{l}\text { Everolimus + } \\
\text { letrazole }\end{array}$ & Oral everolimus and oral letrozole on days 1-28 & OS and PFS \\
\hline NCT00886691 & II & $\begin{array}{l}\text { Ovarian cancer, fallopian } \\
\text { tube cancer, primary } \\
\text { peritoneal cavity cancer }\end{array}$ & $\begin{array}{l}\text { Everolimus and } \\
\text { bevacizumab }\end{array}$ & $\begin{array}{l}\text { Bevacizumab IV over 30-90 minutes on } \\
\text { days } 1 \text { and } 15 \\
\text { Oral Everolimus once daily on days 1-28 }\end{array}$ & PFS \\
\hline
\end{tabular}


- Table 1 Ongoing trials on mTor inhibitors in ovarian cancer. (Continued)

\begin{tabular}{|c|c|c|c|c|c|}
\hline $\begin{array}{l}\text { ClinicalTrials.Gov } \\
\text { Identification } \\
\text { number }\end{array}$ & $\begin{array}{l}\text { Phase } \\
\text { study }\end{array}$ & Population & Scheduled & Course & Primary outcome \\
\hline NCT01281514 & I & $\begin{array}{l}\text { Relapsed ovarian epi- } \\
\text { thelial, fallopian tube, or } \\
\text { peritoneal cavity cancer }\end{array}$ & $\begin{array}{l}\text { Everolimus, } \\
\text { carboplatin } \\
\text { and PLD }\end{array}$ & $\begin{array}{l}\text { Carboplatin (IV) on day } 1 \\
\text { PLD (IV) on day } 1 \\
\text { Everolimus orally once daily on days } 1-28 \text {. } \\
28 \text { days cycle repeated for } 6 \text { courses }\end{array}$ & $\begin{array}{l}\text { Safety and } \\
\text { feasibility }\end{array}$ \\
\hline NCT00982631 & $\mathrm{lb}$ & $\begin{array}{l}\text { Advanced recurrent } \\
\text { ovarian endometrial and } \\
\text { breast cancer }\end{array}$ & $\begin{array}{l}\text { Temsirolimus/ } \\
\text { PLD }\end{array}$ & $\begin{array}{l}28 \text { days cycle } \\
\text { Temsirolimus iv once weekly in a dose escalating } \\
\text { study scheme }\end{array}$ & $\begin{array}{l}\text { MTD, pharmaco- } \\
\text { kinetic parameters }\end{array}$ \\
\hline NCT01460979 & ॥ & $\begin{array}{l}\text { Platinum-refractory ovar- } \\
\text { ian carcinoma or advanced } \\
\text { endometrial carcinoma }\end{array}$ & Temsirolimus & $\begin{array}{l}25 \text { mg weekly } \\
\text { IV } \\
\text { until progression } \\
\text { Evaluation every } 8 \text { weeks }\end{array}$ & $\begin{array}{l}\text { Activity, tolerability } \\
\text { and safety of the } \\
\text { drug }\end{array}$ \\
\hline NCT01196429 & II & $\begin{array}{l}\text { FIGO stage III-IV (first line) } \\
\text { Clear cell ovarian cancer }\end{array}$ & $\begin{array}{l}\text { Temsirolimus, } \\
\text { carboplatin, } \\
\text { and paclitaxel }\end{array}$ & $\begin{array}{l}\text { Paclitaxel IV over } 3 \text { hours and } \\
\text { Carboplatin IV over } 30 \text { minutes on day } 1 \text { and } \\
\text { Temsirolimus IV on days } 1 \text { and } 8 \\
3 \text { weeks cycle repeated for } 6 \text { courses }\end{array}$ & OS and PFS \\
\hline NCT01010126 & II & $\begin{array}{l}\text { FIGO stage III-IV endo- } \\
\text { metrial cancer, ovarian } \\
\text { cancer, fallopian tube } \\
\text { cancer, uterine corpus } \\
\text { cancer }\end{array}$ & $\begin{array}{l}\text { Temsirolimus } \\
\text { and } \\
\text { bevacizumab }\end{array}$ & $\begin{array}{l}\text { Temsirolimus IV on days } 1,8,15 \text {, and } 22 \\
\text { Bevacizumab IV over } 30-90 \text { minutes on } \\
\text { days } 1 \text { and } 15 \\
28 \text { days cycles. Courses repeat in absence of dis- } \\
\text { ease progression }\end{array}$ & $\begin{array}{l}\text { Progression free } \\
\text { survival and tumor } \\
\text { response rate }\end{array}$ \\
\hline NCT01065662 & $\mathrm{I} / \mathrm{lb}$ & $\begin{array}{l}\text { Recurrent/refractory } \\
\text { gynecological malig- } \\
\text { nancies }\end{array}$ & $\begin{array}{l}\text { Temsirolimus } \\
\text { and cediranib }\end{array}$ & $\begin{array}{l}\text { Temsirolimus on days } 1,8,15 \text { and } 22 \text { of each cycle } \\
\text { Cediranib orally daily } \\
28 \text { days cycle }\end{array}$ & $\begin{array}{l}\text { Maximum tolerated } \\
\text { dose }\end{array}$ \\
\hline NCT01155258 & 1 & Advanced solid tumors & $\begin{array}{l}\text { Temsirolimus } \\
\text { and vinorelbine }\end{array}$ & $\begin{array}{l}28 \text { days cycles. Courses repeat in absence } \\
\text { of disease progression } \\
\text { Temsirolimus IV over } 30-60 \text { minutes on } \\
\text { days } 1,8,15 \text {, and } 22 \\
\text { Vinorelbine IV over } 5-10 \text { minutes on days } 1 \\
\text { and } 15\end{array}$ & $\begin{array}{l}\text { Tumor response } \\
\text { rate and maximum } \\
\text { tolerated dose }\end{array}$ \\
\hline NCT01256268 & 1 & $\begin{array}{l}\text { Recurrent or metastatic } \\
\text { endometrial cancer/ } \\
\text { recurrent or metastatic } \\
\text { ovarian cancer }\end{array}$ & $\begin{array}{l}\text { Carboplatin, } \\
\text { paclitaxel and } \\
\text { ridaforolimus }\end{array}$ & $\begin{array}{l}\text { Ridaforolimus } 20-40 \mathrm{mg} \\
\text { Paclitaxel } 175 \mathrm{mg} / \mathrm{m}^{2} \mathrm{IV} \text { and } \\
\text { Carboplatin (AUC } 5 \text { to } 6 \text { ) on day } 1 \text { of each } \\
3 \text { week cycle } \\
\text { Treatment will continue until disease progression } \\
\text { or adverse events }\end{array}$ & $\begin{array}{l}\text { Preliminary efficacy } \\
\text { and maximum } \\
\text { tolerated dose }\end{array}$ \\
\hline NCT01281514 & I & $\begin{array}{l}\text { Recurrent ovarian, } \\
\text { fallopian tube or peritoneal } \\
\text { cancer }\end{array}$ & $\begin{array}{l}\text { Carboplatin }+ \\
\text { PLD }+ \\
\text { everolimus }\end{array}$ & $\begin{array}{l}28 \text { days cycles for } 6 \text { months } \\
\text { Carboplatin intravenously IV + PLD IV on day } 1+ \\
\text { everolimus orally once daily on days } 1-28 \text {. }\end{array}$ & $\begin{array}{l}\text { Maximum tolerated } \\
\text { dose (MTD) } \\
\text { Safety and } \\
\text { tolerability } \\
\text { Efficacy }\end{array}$ \\
\hline NCT02208375 & $1 / 11$ & $\begin{array}{l}\text { Recurrent endometrial, } \\
\text { triple negative breast, } \\
\text { ovarian, primary peri- } \\
\text { toneal, or fallopian tube } \\
\text { cancer }\end{array}$ & $\begin{array}{l}\text { Olaparib }+ \\
\text { mTORC1/2 } \\
\text { inhibitor } \\
\text { AZD2014 } \\
\text { or } \\
\text { AKT inhibitor } \\
\text { AZD5363 }\end{array}$ & $\begin{array}{l}\text { Monthly cycles } \\
\text { Olaparib + AZD2014 (continuous or intermittent } \\
\text { dosing) } \\
\text { Or Olaparib + AZD5363 (intermittent dosing) } \\
\text { Treatment will continue until disease progression } \\
\text { or adverse events }\end{array}$ & $\begin{array}{l}\text { Tumor response } \\
\text { rate and maximum } \\
\text { tolerated dose }\end{array}$ \\
\hline
\end{tabular}

Updated 31th March 2017 
pain, diarrhea, nausea and hypertension. Clinical responses were stable disease in the great majority of cases.

\section{Problematic Aspects Regarding mTor Inhibitors}

The precise mechanism of drug resistance remains unknown. Loss of the established negative feedback to the drug seems to be involved in the resistance mechanisms.

The selective affinity of mTor inhibitors for mTORC1 and lack of suppression of mTORC2 have been suggested as a mechanism of drug resistance.

Indeed, mTORC2 engages in an AKT-activation loop in response to mTORC1 inhibition [38]. New inhibitors that target both mTORC1 and mTORC2, or even PI3K inhibitors in combined regimens could be the right way of overcoming drug resistance.

Another crucial aspect of the application of mTor inhibitors in ovarian cancer is the selection of correct patients, since it seems that rapamycin and its analogues are more effective in tumors that express high activity of PI3K/AKT/mTORC1 pathways such as ovarian clear cell carcinoma and endometrioid ovarian cancer [49]. Additionally, patients presenting PIK3CA alterations respond better than patients with functioning PIK3CA [39].

Furthermore, a comprehensive identification of the toxicity profile of ovarian cancer patients treated with mTOR inhibitors is still strongly needed. Larger studies on breast cancer patients suggest that the most common adverse events of mTOR inhibitors include stomatitis (all grades: approximately $60 \%$ ), noninfectious pneumonitis (15\%), rash (40\%), hyperglycemia (15\%), and immunosuppression (40\%) [67]. Future results derived from the currently ongoing phase II clinical trials on the use of mTOR inhibitors in ovarian cancer will better elucidate this crucial aspect, pivotal for establishing the integration of these compounds into the clinical practice of ovarian cancer treatment.

\section{Conclusions}

$\mathrm{PI3K} / \mathrm{AKT} / \mathrm{mTORC} 1$ pathway inhibitors constitute a group of new target therapies for the treatment of ovarian cancer, given the highly expressed activity of this pathway in the pathogenesis and progression of ovarian carcinoma. Promising preliminary results in phase I and II trials encourage further studies. However, no phase III trials on ovarian cancer patients have been reported yet.

A selection of the cancer population that could mostly benefit from these new drugs and better understanding of how to integrate these new medications are pivotal for improving the current management of ovarian cancer.

\section{Conflict of Interest}

The authors declare that they have no conflict of interest.

\section{References}

[1] Marchetti C, Gasparri ML, Ruscito I et al. Advances in anti-angiogenic agents for ovarian cancer treatment: the role of trebananib (AMG 386). Crit Rev Oncol Hematol 2015; 94: 302-310

[2] Leone Roberti Maggiore U, Bellati F, Ruscito I et al. Monoclonal antibodies therapies for ovarian cancer. Expert Opin Biol Ther 2013; 13: 739764

[3] Bellati F, Napoletano C, Ruscito I et al. Past, present and future strategies of immunotherapy in gynecological malignancies. Curr Mol Med 2013; 13: 648-669

[4] Marchetti C, Imperiale L, Gasparri ML et al. Olaparib, PARP1 inhibitor in ovarian cancer. Expert Opin Investig Drugs 2012; 21: 1575-1584

[5] Bellati F, Napoletano C, Gasparri ML et al. Monoclonal antibodies in gynecological cancer: a critical point of view. Clin Dev Immunol 2011; 2011: 890758

[6] Bellati F, Napoletano C, Gasparri ML et al. Current knowledge and open issues regarding bevacizumab in gynaecological neoplasms. Crit Rev Oncol Hematol 2012; 83: 35-46

[7] Attar R, Gasparri ML, Donato VD et al. Ovarian cancer: interplay of vitamin D signaling and miRNA action. Asian Pac J Cancer Prev 2014; 15: 3359-3362

[8] Musella A, Marchetti C, Gasparri ML et al. PARP inhibition: a promising therapeutic target in ovarian cancer. Cell Mol Biol (Noisy-le-grand) 2015; 61: 44-61

[9] Marchetti C, De Felice F, Palaia I et al. Efficacy and toxicity of bevacizumab in recurrent ovarian disease: an update meta-analysis on phase III trials. Oncotarget 2016; 7: 13221-13227

[10] Ruscito I, Gasparri ML, Marchetti C et al. Cediranib in ovarian cancer: state of the art and future perspectives. Tumour Biol 2016; 37: 28332839

[11] Gasparri ML, Savone D, Besharat RA et al. Circulating tumor cells as trigger to hematogenous spreads and potential biomarkers to predict the prognosis in ovarian cancer. Tumour Biol 2016; 37: 71-75

[12] Gasparri ML, Attar R, Palaia I et al. Tumor infiltrating lymphocytes in ovarian cancer. Asian Pac J Cancer Prev 2015; 16: 3635-3638

[13] Klukovits A, Schally AV, Szalontay L et al. Novel antagonists of growth hormone-releasing hormone inhibit growth and vascularization of human experimental ovarian cancers. Cancer 2015; 118: 670-680

[14] Papadia A, Schally AV, Halmos G et al. Growth hormone-releasing hormone antagonists inhibit growth of human ovarian cancer. Horm Metab Res 2011; 43: 816-820

[15] Verri E, Guglielmini P, Puntoni M et al. HER2/neu oncoprotein overexpression in epithelial ovarian cancer: evaluation of its prevalence and prognostic significance. Clinical study. Oncology 2005; 68: 154-161

[16] Papadia A, Morotti M. Diaphragmatic surgery during cytoreduction for primary or recurrent epithelial ovarian cancer: a review of the literature. Arch Gynecol Obstet 2013; 287: 733-741

[17] Gasparri ML, Grandi G, Bolla D et al. Hepatic resection during cytoreductive surgery for primary or recurrent epithelial ovarian cancer. J Cancer Res Clin Oncol 2016; 142: 1509-1520

[18] Gasparri ML, Panici PB, Papadia A. Primary chemotherapy versus primary surgery for ovarian cancer. Lancet 2015; 386: 2142-2143

[19] Kehoe S, Hook J, Nankivell M et al. Primary chemotherapy versus primary surgery for newly diagnosed advanced ovarian cancer (CHORUS): an open-label, randomised, controlled, non-inferiority trial. Lancet 2015; 386: 249-257

[20] Papadia A, Remorgida V, Salom EM et al. Laparoscopic pelvic and paraaortic lymphadenectomy in gynecologic oncology. J Am Assoc Gynecol Laparosc 2004; 11: 297-306 
[21] Papadia A, Ragni N, Salom EM. The impact of obesity on surgery in gynecological oncology: a review. Int J Gynecol Cancer 2006; 16: 944-952

[22] Aletti GD, Dowdy SC, Gostout BS et al. Quality improvement in the surgical approach to advanced ovarian cancer: the Mayo Clinic experience. J Am Coll Surg 2009; 208: 614-620

[23] Siegel RL, Miller KD, Jemal A. Cancer statistics. CA Cancer ] Clin 2015; 65 : 5-29

[24] Online: cancer.gov

[25] Jayson GC, Kohn EC, Kitchener HC et al. Ovarian cancer. Lancet 2014; 384: 1376-1388

[26] Miller DS, Blessing JA, Krasner CN et al. Phase II evaluation of pemetrexed in the treatment of recurrent or persistent platinum-resistant ovarian or primary peritoneal carcinoma: a study of the Gynecologic Oncology Group. J Clin Oncol 2009; 27: 2686-2691

[27] Cancer Genome Atlas Research Network. Integrated genomic analyses of ovarian carcinoma. Nature 2011; 474: 609-615

[28] Hay N, Sonenberg N. Upstream and downstream of mTOR. Genes Dev 2004; 18: 1926-1945

[29] Huang J, Zhang L, Greshock J et al. Frequent genetic abnormalities of the $\mathrm{PI3K} / \mathrm{AKT}$ pathway in primary ovarian cancer predict patient outcome. Genes Chromosomes Cancer 2011; 50: 606-618

[30] Mabuchi S, Kuroda H, Takahashi R et al. The PI3K/AKT/mTOR pathway as a therapeutic target in ovarian cancer. Gynecol Oncol 2015; 137: 173179

[31] Cheaib B, Auguste A, Leary A. The PI3K/Akt/mTOR pathway in ovarian cancer: therapeutic opportunities and challenges. Chin J Cancer 2015; 34: 4-16

[32] Whitman M, Downes CP, Keeler M et al. Type I phosphatidylinositol kinase makes a novel inositol phospholipid, phosphatidylinositol-3-phosphate. Nature 1988; 332: 644-646

[33] Fruman DA, Rommel C. PI3K and cancer: lessons, challenges and opportunities. Nat Rev Drug Discov 2014; 13: 140-156

[34] Maehama T, Dixon JE. The tumor suppressor, PTEN/MMAC1, dephosphorylates the lipid second messenger, phosphatidylinositol 3,4,5-trisphosphate. J Biol Chem 1998; 273: 13375-13378

[35] Gewinner C, Wang ZC, Richardson A et al. Evidence that inositol polyphosphate 4-phosphatase type II is a tumor suppressor that inhibits PI3K signaling. Cancer Cell 2009; 16: 115-125

[36] Laplante M, Sabatini DM. mTOR signaling in growth control and disease. Cell 2012; 149: 274-293

[37] Kunz J, Henriquez R, Schneider $U$ et al. Target of rapamycin in yeast, TOR2, is an essential phosphatidylinositol kinase homolog required for G1 progression. Cell 1993; 73: 585-596

[38] Delgoffe GM, Pollizzi KN, Waickman AT et al. The kinase mTOR regulates the differentiation of helper $T$ cells through the selective activation of signaling by mTORC1 and mTORC2. Nat Immunol 2011; 12: 295-303

[39] Li H, Zeng J, Shen K. PI3K/AKT/mTOR signaling pathway as a therapeutic target for ovarian cancer. Arch Gynecol Obstet 2014; 290: 1067-1078

[40] Bai H, Li H, Li W et al. The PI3K/AKT/mTOR pathway is a potential predictor of distinct invasive and migratory capacities in human ovarian cancer cell lines. Oncotarget 2014; 6: 25520-25532

[41] Levine DA, Bogomolniy F, Yee C] et al. Frequent mutation of the PIK3CA gene in ovarian and breast cancers. Clin Cancer Res 2005; 11: 28752878

[42] Cancer Genome Atlas Research Network. Integrated genomic analyses of ovarian carcinoma. Nature 2011; 474: 609-615

[43] Kurman RJ, Shih leM. The dualistic model of ovarian carcinogenesis: revisited, revised, and expanded. Am J Pathol 2016; 186: 733-747

[44] Kuo KT, Mao TL, Jones $S$ et al. Frequent activating mutations of PIK3CA in ovarian clear cell carcinoma. Am J Pathol 2009; 174: 1597-1601
[45] Philp AJ, Campbell IG, Leet C et al. The phosphatidylinositol 3'-kinase p 85alpha gene is an oncogene in human ovarian and colon tumors. Cancer Res 2001; 61: 7426-7429

[46] Tanwar PS, Zhang L, Kaneko-Tarui T et al. Mammalian target of rapamycin is a therapeutic target for murine ovarian endometrioid adenocarcinomas with dysregulated Wnt/ $\beta$-catenin and PTEN. PLoS One 2011; 6: e20715

[47] Pritchard DI. Sourcing a chemical succession for cyclosporin from parasites and human pathogens. Drug Discov Today 2005; 10: 688-691

[48] Guertin DA, Sabatini DM. An expanding role for mTOR in cancer. Trends Mol Med 2005; 11: 353-361

[49] Liu P, Cheng H, Roberts TM et al. Targeting the phosphoinositide 3-kinase pathway in cancer. Nat Rev Drug Discov 2009; 8: 627-644

[50] Faivre S, Kroemer G, Raymond E. Current development of mTOR inhibitors as anticancer agents. Nat Rev Drug Discov 2006; 5: 671-688

[51] Behbakht K, Sill MW, Darcy KM et al. Phase II trial of the mTOR inhibitor, temsirolimus and evaluation of circulating tumor cells and tumor biomarkers in persistent and recurrent epithelial ovarian and primary peritoneal malignancies: a Gynecologic Oncology Group study. Gynecol Oncol 2011; 123: 19-26

[52] Temkin SM, Yamada SD, Fleming GF. A phase I study of weekly temsirolimus and topotecan in the treatment of advanced and/or recurrent gynecologic malignancies. Gynecol Oncol 2010; 117: 473-476

[53] Takano M, Kikuchi Y, Kudoh K et al. Weekly administration of temsirolimus for heavily pretreated patients with clear cell carcinoma of the ovary: a report of six cases. Int J Clin Oncol 2011; 16: 605-609

[54] Kollmannsberger C, Hirte H, Siu LL et al. Temsirolimus in combination with carboplatin and paclitaxel in patients with advanced solid tumors: a NCIC-CTG, phase I, open-label dose-escalation study (IND 179). Ann Oncol 2012; 23: 238-244

[55] Boers-Sonderen M], de Geus-Oei LF, Desar IM et al. Temsirolimus and pegylated liposomal doxorubicin (PLD) combination therapy in breast, endometrial, and ovarian cancer: phase lb results and prediction of clinical outcome with FDG-PET/CT. Target Oncol 2014; 9: 339-347

[56] Piha-Paul SA, Wheler J], Fu S et al. Advanced gynecologic malignancies treated with a combination of the VEGF inhibitor bevacizumab and the mTOR inhibitor temsirolimus. Oncotarget 2014; 5: 1846-1855

[57] Emons G, Kurzeder C, Schmalfeldt B et al. Temsirolimus in women with platinum-refractory/resistant ovarian cancer or advanced/recurrent endometrial carcinoma. A phase II study of the AGO-study group (AGOGYN8). Gynecol Oncol 2016; 140: 450-456

[58] Vlahovic G, Meadows KL, Uronis HE et al. A phase I study of bevacizumab, everolimus and panitumumab in advanced solid tumors. Cancer Chemother Pharmacol 2012; 70: 95-102

[59] Guo H, Zhong Y, Jackson AL et al. Everolimus exhibits anti-tumorigenic activity in obesity-induced ovarian cancer. Oncotarget 2016; 7: 2033820356

[60] Perl A. mTOR activation is a biomarker and a central pathway to autoimmune disorders, cancer, obesity, and aging. Ann N Y Acad Sci 2015; 1346: 33-44

[61] Zhang $D$, Xia $H$, Zhang $W$ et al. The anti-ovarian cancer activity by WYE-132, a mTORC1/2 dual inhibitor. Tumour Biol 2016; 37: 13271336

[62] Schrauwen S, Depreeuw ], Coenegrachts L et al. Dual blockade of PI3K/ AKT/mTOR (NVP-BEZ235) and Ras/Raf/MEK (AZD6244) pathways synergistically inhibit growth of primary endometrioid endometrial carcinoma cultures, whereas NVP-BEZ235 reduces tumor growth in the corresponding xenograft models. Gynecol Oncol 2015; 138: 165-173

[63] Bogani G, Chiappa V, Lorusso D et al. Treatment of recurrent endometrial carcinoma: progress toward a more personalized approach. J Clin Oncol 2015; 33: 3516 
[64] Hussain AR, Al-Romaizan M, Ahmed M et al. Dual targeting of mTOR activity with Torin2 potentiates anti-cancer effects of cisplatin in epithelial ovarian cancer. Mol Med 2015; 21: 466-478. doi:10.2119/ molmed.2014.00238

[65] Wang D, Wang M, Jiang N et al. Effective use of PI3K inhibitor BKM120 and PARP inhibitor olaparib to treat PIK3CA mutant ovarian cancer. Oncotarget 2016; 7: 13153-13166
[66] Taylor SE, Chu T, Edwards RP et al. Phase II study of everolimus (EV) and bevacizumab (BEV) in recurrent ovarian, peritoneal, and fallopian tube cancer. J Clin Oncol 2016; 34 (Suppl.): Abstr. 5552

[67] Chia S, Gandhi S, Joy AA et al. Novel agents and associated toxicities of inhibitors of the pi3 $\mathrm{k} / \mathrm{Akt} / \mathrm{mtor}$ pathway for the treatment of breast cancer. Curr Oncol 2015; 22: 33-48 